\title{
PHYTOCHEMICAL SCREENING, ANTIMICROBIAL, AND ANTIOXIDANT ACTIVITIES OF ROOT AND LEAF EXTRACTS OF LEUCAS ASPERA
}

\author{
VASUDHA K, ARCHANA D, MUTYALAMMA B, KISHORI B*
}

Department of Biotechnology, Sri Padmavati Mahila Visvavidyalayam (Women's University), Tirupati - 517 502, Andhra Pradesh, India. Email: kktinku@rediffmail.com

Received: 13 August 2018, Revised and Accepted: 26 December 2018

\section{ABSTRACT}

Objective: The present study was designed to evaluate the phytochemical screening, antimicrobial, and antioxidant activities from the roots and leaves of Leucas aspera.

Methods: The phytochemical screening and Fourier transform infrared (FTIR) analysis of root and leaf extracts were studied using standard methods. The disk diffusion method was performed to analyze the antimicrobial activity of aqueous extract, methanol extract and hexane extract of root and leaf against to selected bacterial and fungal strains. Antibiotics, streptomycin and nystatin were used as standards for bacteria and fungi, respectively. The antioxidant activity of the extracts was evaluated by 1,1-diphenyl-2-picrylhydrazyl (DPPH) and scavenging of $\mathrm{H}_{2} \mathrm{O}_{2}$ free radicals.

Results: Preliminary phytochemical screening of extracts exhibited the presence of carbohydrates, proteins, amino acids, steroids flavonoids, terpenoids, saponins, alkaloids, tannins, and phlobatannins. Leaf extracts exhibited effective antibacterial and antifungal activities compared with root extracts against all the tested bacteria and fungi. ME of the leaves exhibited highest antibacterial activity against Staphylococcus aureus $(12.8 \pm 0.31 \mathrm{~mm})$, followed by Bacillus subtilis $(11.4 \pm 0.3 \mathrm{~mm})$, Escherichia coli $(9.8 \pm 0.21 \mathrm{~mm})$, and Pseudomonas aeruginosa $(7.3 \pm 0.29 \mathrm{~mm})$. Leaf extracts of $L$. aspera showed effective scavenging activity compared with root extracts. ME of the leaves showed maximum scavenging activities of 38.39 and $36.85 \%$, respectively, against $\mathrm{DPPH}$ and $\mathrm{H}_{2} \mathrm{O}_{2}$ free radicals with half maximal inhibitory concentration values of $136.17 \mathrm{and} 142.42 \mu \mathrm{g} / \mathrm{ml}$.

Conclusion: Phytochemical analysis and FTIR spectrum revealed that different plant secondary metabolites particularly alkaloids, terpenoids, and flavonoids could be responsible for antimicrobial and antioxidant activities of $L$. aspera leaf extracts.

Keywords: Leucas aspera, Antimicrobial activity, Antioxidant activity, Fourier transform infrared analysis.

(C) 2019 The Authors. Published by Innovare Academic Sciences Pvt Ltd. This is an open access article under the CC BY license (http://creativecommons. org/licenses/by/4. 0/) DOI: http://dx.doi.org/10.22159/ajpcr.2019.v12i3.29085

\section{INTRODUCTION}

Traditional medicine is an integral part of the primary health-care system in many countries such as India, China, and Sri Lanka. Plants are good examples and a number of plant species are known to have medicinal value. India is known for its incredible source of medicinal plants, and large body of evidence has been accumulated to highlight the potential use of medicinal plants against the harmful diseases. Over the past 100 years, development of chemotherapy and technology for the production of synthetic drugs changed the world scenario in medicine. Usage of synthetic drugs against a range of pathogenic microbes is becoming complicated due to non-response/modification of microbes. Moreover, the wide usage of commercial antimicrobial drugs lead to side effects, and most notably, development of drug resistance in the majority of the pathogenic microbes is an another major problem. To minimize the synthetic antimicrobial drugs and to reduce side effects, screening of plants with antimicrobial properties is growing day-by-day.

It is well known that several medicinal plants have been used to treat microbial infections from 1000 years [1,2]. A number of studies reported the antimicrobial properties of plants [3-9]. In addition to medicinal value, there is an increasing interest toward natural antioxidants present in plants. Antioxidant molecules have the capability to quench free radicals and remediate the effects caused by reactive oxygen species and have roles in the prevention of degenerative diseases which caused by oxidative stress [10]. Medicinal plants are rich sources of antioxidant molecules such as flavonoids, triterpenoids, tannins, coumarins, quinones, vitamins, and polyphenolic compounds and it was reported by several studies [11-13].

Numerous studies have investigated the presence of pharmacological properties from several medicinal plants. Since of more importance to the individual compounds, the recent research is in much focus to isolate and identify the specific compounds using various methods of recent technology. The most popular methods such as high-performance liquid chromatography, gas chromatography-mass spectrometry (MS), matrix-assisted laser desorption ionization time-of-flight, MS-MS, and Fourier transform infrared (FTIR) are in use to isolate the pure compounds from various parts of the plant [14-16].

Leucas aspera, belonging to the family of Lamiaceae or Labiatae, is a common aromatic herb found in Africa, temperate and tropical countries of Asia. It is generally called as "Thumbai," widely distributed throughout India. The plant is reported to contain various phytochemicals such as oleanolic acid, ursolic acid, $\alpha$-sitosterol, $\beta$-sitosterol, reducing sugars, diterpenes, glycosides, (-)isololiolide, linifolioside, nicotine, macelignan, acacetin, apigenin, myristargenol B, machilin C, and (-)chicanine [17]. In addition to the above compounds, steroids, triterpenes, phenols, flavonoids, tannins, and long-chain aliphatic compounds were also reported in L. aspera [18-20]. L. aspera possesses various medicinal values including, analgesic, anticancer, antidiabetic, antirheumatic, anti-inflammatory, antibacterial, antifungal, cytotoxic, and antioxidant activity $[17,20]$. There are large body of literature which is available on antibacterial and other medicinal values of $L$. aspera. However, studies on antifungal activity and phytochemical screening different parts of $L$. aspera are in adequate.

Based on the medicinal properties of L. aspera, the present study was aimed to evaluate the antimicrobial activity of root and leaf extracts (aqueous extract [AE], methanol extract [ME], and hexane extract [HE]) of $L$. aspera against a range of selected bacterial and fungal strains. The active compounds were also analyzed by FTIR screening and 
antioxidant properties were also evaluated in the selected extracts of plant parts.

\section{METHODS}

\section{Plant material}

L. aspera plants were collected from Seshachalam hills, Eastern Ghats, Tirupati, Andhra Pradesh, India. The plant $L$. aspera was identified by Dr. Madhavashetty, Asst. Professor, Department of the Botany, S. V. University, Tirupati. The roots and leaves were separately kept for shade dry for a week and made them to fine powder. Later the powders of leaves and roots were subjected to Soxhlet extraction with different solvents including aqueous, methanol, and hexane.

\section{Preparation of extracts}

Different extracts were prepared using $100 \mathrm{~g}$ of powdered samples of leaves and roots were separately taken in $1000 \mathrm{ml}$ of aqueous, methanol, and hexane solvents. Extraction was carried out using Soxhlet extractor at boiling point temperature of aqueous, methanol, and hexane solvents for $12 \mathrm{~h}$. Using Whatman filter paper, the extracts were filtered then the filtrate was subjected for drying and redissolved in $50 \%(\mathrm{v} / \mathrm{v})$ different solvents separately each containing $2.0 \mathrm{mg} / \mathrm{ml}$ extract and stored in airtight container.

\section{Phytochemical screening}

Phytochemical screening was performed using standard protocols to identify the presence of carbohydrates, cholesterols, amino acids, proteins, steroids, saponins, flavonoids, alkaloids, tannins, and phlobatannins [21].

\section{FTIR analysis of leaf and root extracts}

The dried powders of different extracts were made as pellet by taking $2 \mathrm{mg}$ of the sample mixed with $200 \mathrm{mg} \mathrm{KBr}$ (FT-IR grade). The sample pellet kept into the sample holder and recorded the spectra range between 4000 and $450 \mathrm{~cm}^{-1}$ in FTIR spectroscopy [22]

\section{Antimicrobial activity}

\section{Microorganisms}

To screen of antimicrobial activity of L. aspera roots and leaves, Grampositive, Gram-negative bacteria such as Bacillus subtilis, Staphylococcus aureus, Escherichia coli, and Pseudomonas aeruginosa and fungi Candida albicans and Aspergillus niger were used. All the cultures were obtained from the Department of Biotechnology, Sri Padmavati Mahila Visvavidyalayam, Tirupati.

\section{Antibacterial activity}

Antibacterial activity of the different extracts of roots and leaves of $L$. aspera was evaluated against selected bacteria according to the Kirby-Bauer disk diffusion method [23]. Actively growing bacterial culture of $200 \mu \mathrm{l}$ was evenly spread on the surface of nutrient agar plates using the sterile glass rod. The extracts were prepared with the concentrations of $25,50,75$, and $100 \mu \mathrm{g} / \mathrm{ml}$ and antibacterial activity was evaluated by placing the discs of different concentrations on the nutrient agar plates with standard antibiotic, streptomycin and plates were kept for incubation at $37^{\circ} \mathrm{C}$ for $24 \mathrm{~h}$. The diameters of the inhibitory zones were recorded after incubation.

\section{Antifungal activity}

Antifungal activity of the different extracts of roots and leaves of L. aspera was evaluated against C. albicans and Aspergillus niger using disk diffusion method [24]. $200 \mu \mathrm{l}$ of actively growing fungal inoculum was swabbed on the surface of potato dextrose agar (PDA) plates. The antibiotic discs prepared with $25,50,75$, and $100 \mu \mathrm{g} / \mathrm{ml}$ concentrations were placed on the PDA plates with standard antibiotic, nystatin. The PDA plates were incubated at $24^{\circ} \mathrm{C}$ for $72 \mathrm{~h}$. After incubation, the diameters of zone of inhibitions were measured.

\section{Antioxidant activity}

\section{1,1-diphenyl-2-picrylhydrazyl (DPPH) radical scavenging assay}

In vitro, antioxidant activity of the root and leaf extracts was evaluated by DPPH free radical scavenging assay [25]. $1 \mathrm{ml}$ of each extract at selected concentrations $(25,50,75$, and $100 \mu \mathrm{g} / \mathrm{ml})$ was mixed with $2 \mathrm{ml}$ of DPPH solution. The reaction mixture was incubated for $30 \mathrm{~min}$ at room temperature, and absorbance was recorded at $517 \mathrm{~nm}$. Ascorbic acid was used as a standard. The DPPH scavenging activity was calculated using the following formula:

\%DPPH scavenging activity=[(Absorbance of Control-Absorbance of Test sample)/Absorbance of Control] $\times 100$

The amount of sample necessary to decrease the absorbance of DPPH by $50 \%$ (half maximal inhibitory concentration $\left[\mathrm{IC}_{50}\right]$ ) was calculated graphically.

\section{$\mathrm{H}_{2} \mathrm{O}_{2}$ radical scavenging assay}

Antioxidant activity of the different extracts of $L$. aspera was further proved by $\mathrm{H}_{2} \mathrm{O}_{2}$ radical scavenging assay [26]. $2 \mathrm{ml}$ of $\mathrm{H}_{2} \mathrm{O}_{2}$ solution prepared in $40 \mathrm{mM}$ phosphate buffer $(\mathrm{pH}$ 7.4) was added to $1 \mathrm{ml}$ of different concentrations, $25,50,75$, and $100 \mu \mathrm{g} / \mathrm{ml}$ of extracts separately and kept in the dark at room temperature for $20 \mathrm{~min}$. After incubation, absorbance was measured at $230 \mathrm{~nm}$ for each test sample. Ascorbic acid was used as a standard. The percentage of radical scavenging activity (RSA) was calculated using the equation.

RSA (\%) $=[($ Absorbance of Control - Absorbance of Test sample)/ Absorbance of Control] $\times 100$

\section{RESULTS}

The present study reports the phytochemical screening, FTIR analysis, antimicrobial, and antioxidant activities of different extracts of roots and leaves of L. aspera.

\section{Phytochemical screening}

Phytochemical screening of the $L$. aspera suggests the presence of major phytochemicals in the root and leaf extracts (Tables 1 and 2). $\mathrm{ME}$ and $\mathrm{HE}$ of roots and leaves showed the presence of carbohydrates, cholesterols, proteins, amino acids, steroids, saponins, flavonoids, alkaloids, tannins, and phlobatannins, whereas, AEs of both root and

Table 1: Phytochemical screening in leaf extracts of $L$. aspera

\begin{tabular}{llll}
\hline Phytochemical & AE & ME & HE \\
\hline Carbohydrates & + & + & + \\
Cholesterol & - & + & + \\
Steroids & - & + & + \\
Proteins & + & + & + \\
Amino acids & + & + & + \\
Flavonoids & + & + & + \\
Terpenoids & + & + & + \\
Saponins & + & + & + \\
Tannins & + & + & + \\
Phlobatannins & + & + & + \\
\hline
\end{tabular}

+Indicates the presence; -indicates the presence. L. aspera: Lucas aspera,

$\mathrm{AE}$ : Aqueous extract, ME: Methanol extract, HE: Hexane extract

Table 2: Phytochemical screening in root extracts of $L$. aspera

\begin{tabular}{llll}
\hline Phytochemical & AE & ME & HE \\
\hline Carbohydrates & + & + & + \\
Cholesterol & - & + & + \\
Steroids & - & + & + \\
Proteins & + & + & + \\
Amino acids & + & + & + \\
Flavonoids & + & + & + \\
Terpenoids & + & + & + \\
Saponins & + & + & + \\
Tannins & + & + & + \\
Phlobatannins & + & + & + \\
\hline
\end{tabular}

+Indicates the presence; -indicates the presence. L. aspera: Lucas aspera,

$\mathrm{AE}$ : Aqueous extract, ME: Methanol extract, HE: Hexane extract 
leaf also showed the presence of all phytochemicals except cholesterols and steroids (Tables 1 and 2).

\section{FTIR analysis of the plant sample}

FTIR analysis of leaf and root extracts of L. aspera was carried out to reveal the functional groups present in the leaves and roots. FTIR spectrum of different extracts leaves of the L. aspera (Fig. 1a-c) showed the major peaks at 3334.04, 2924.18, 1618.19, 1322.72, 1251.81, $1029.36,476.53$, and $433.23 \mathrm{~cm}^{-1}$. The broad peak at $3334.04 \mathrm{~cm}^{-1}$ is responsible for $\mathrm{O}-\mathrm{H}$ stretching of polyphenolic compounds such as flavonoids, nonflavonoids, and triterpenoids. The broad peak at 2924.18 could be due to $\mathrm{C}=0$ stretching of proteins. The broad peak at $1618.19 \mathrm{~cm}^{-1}$ can be corresponding to the amide II group of proteins. The broad peak at $1023.33 \mathrm{~cm}^{-1}$ is also corresponding to $\mathrm{O}-\mathrm{H}$ group of polyphenolic compounds including flavonoids, terpenoids, and nonflavonoids. The remaining other peaks are very narrow which revealed the presence of other compounds such as anhydrides, esters, and carboxylic acids in low amounts.

FTIR spectrum of different extracts of roots of the L. aspera (Fig. 2a-c) showed the major peaks at 3403.33, 2926.36, 2137.34, 1604.93, $1415.14,1263.00,1032.58$, and $533.09 \mathrm{~cm}^{-1}$. The broad peak at $3403.33 \mathrm{~cm}^{-1}$ is responsible for $\mathrm{O}-\mathrm{H}$ stretching of polyhydroxy compounds such as flavonoids, nonflavonoids, and triterpenoids. The broad peak at 2926.36 is responsible for $\mathrm{C}=0$ stretching of proteins. The broad peak at $1604.93 \mathrm{~cm}^{-1}$ can be corresponding to the amide II group of proteins. The broad peak at $1032.58 \mathrm{~cm}^{-1}$ is also corresponding to $\mathrm{O}-\mathrm{H}$ group of polyphenolic compounds including flavonoids, terpenoids, and nonflavonoids.

\section{Antibacterial activity}

Antibacterial activity of the AE, ME, and HE of roots and leaves of the L. aspera was evaluated, and zone of inhibition values of all the extracts was presented in Table 3. All the extracts of roots and leaves showed dose-dependent inhibitory activity against all the tested bacteria. All the extracts showed maximum zone of inhibition at the highest concentration of $100 \mu \mathrm{g} / \mathrm{ml}$ tested. All the prepared extracts of roots and leaves of $L$. aspera displayed the highest inhibitory activity against Gram-positive bacteria compared to Gram-negative bacteria. $\mathrm{ME}$ of leaves formed the maximum inhibition zone of $11.4 \pm 0.3 \mathrm{~mm}$ against $B$. subtilis while $\mathrm{HE}$ and $\mathrm{AE}$ of leaves showed only $8.1 \pm 0.27$ and $7.4 \pm 0.29 \mathrm{~mm}$, respectively, against the same bacteria. ME of leaves displayed the maximum inhibition zone of $12.8 \pm 0.31 \mathrm{~mm}$ against S. aureus while HE and $\mathrm{AE}$ showed only $6.9 \pm 0.26$ and $7.3 \pm 0.25 \mathrm{~mm}$, respectively, against the same bacteria. Similarly, ME of leaves exhibited maximum inhibition zone of $9.8 \pm 0.21 \mathrm{~mm}$ against $E$. coli while $\mathrm{HE}$ and $\mathrm{AE}$ of leaves showed only $6.8 \pm 0.24$ and $6.6 \pm 0.22 \mathrm{~mm}$, respectively, against the same bacteria. ME of leaves exhibited maximum inhibition zone of $7.3 \pm 0.29 \mathrm{~mm}$ against $P$. aeruginosa while $\mathrm{HE}$ and $\mathrm{AE}$ of leaves showed only $5.8 \pm 0.27$ and $6.0 \pm 0.17 \mathrm{~mm}$, respectively, against the same bacteria.

$\mathrm{AE}, \mathrm{ME}$, and $\mathrm{HE}$ of roots of L. aspera showed the highest inhibitory activity against Gram-positive bacteria compared to Gram-negative bacteria. All the extracts of roots showed the highest antibacterial activity against $S$. aureus, followed by B. subtilis, E. coli, and P. aeruginosa. ME of roots exhibited maximum inhibition zone of $5.6 \pm 0.34 \mathrm{~mm}$ against $P$. aeruginosa while $\mathrm{HE}$ and $\mathrm{AE}$ of roots showed only $5.3 \pm 0.24$ and $4.1 \pm 0.23 \mathrm{~mm}$, respectively, against the same bacteria. However, standard drug streptomycin showed $14.2 \mathrm{~mm}, 15.4 \mathrm{~mm}, 12.3 \mathrm{~mm}$, and $13.1 \mathrm{~mm}$ zone of inhibition against to B. subtilis, S. aureus, E. coli, and P. aeruginosa, respectively.

\section{Antifungal activity}

Antifungal activity of the $\mathrm{AE}, \mathrm{ME}$, and $\mathrm{HE}$ of roots and leaves of the L. aspera was evaluated against C. albicans and A. niger; results are represented in Table 4. All the extracts of leaves and roots showed concentration-dependent inhibitory activity against the fungal species. All the extracts of roots and leaves of $L$. aspera showed effective antifungal activity against $A$. niger compared with $C$. albicans. ME of the leaves showed highest antifungal activity compared with HE and $\mathrm{AE}$ of leaves. ME of leaves formed the inhibition zones of $10.3 \pm 0.27$ and

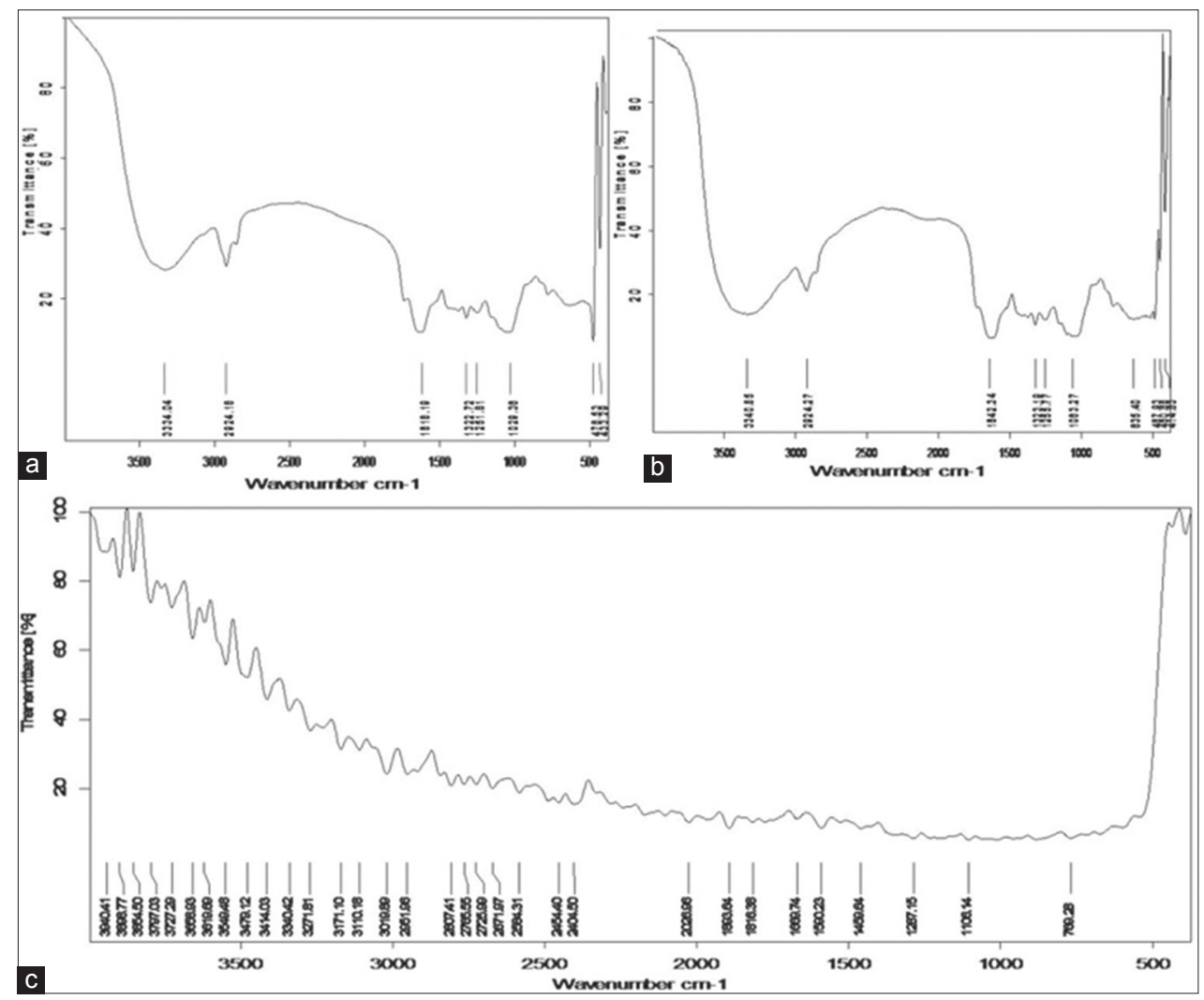

Fig. 1: Fourier transform infrared spectrum of (a) aqueous, (b) hexane, and (c) methanolic extracts of leaves of Lucas aspera 


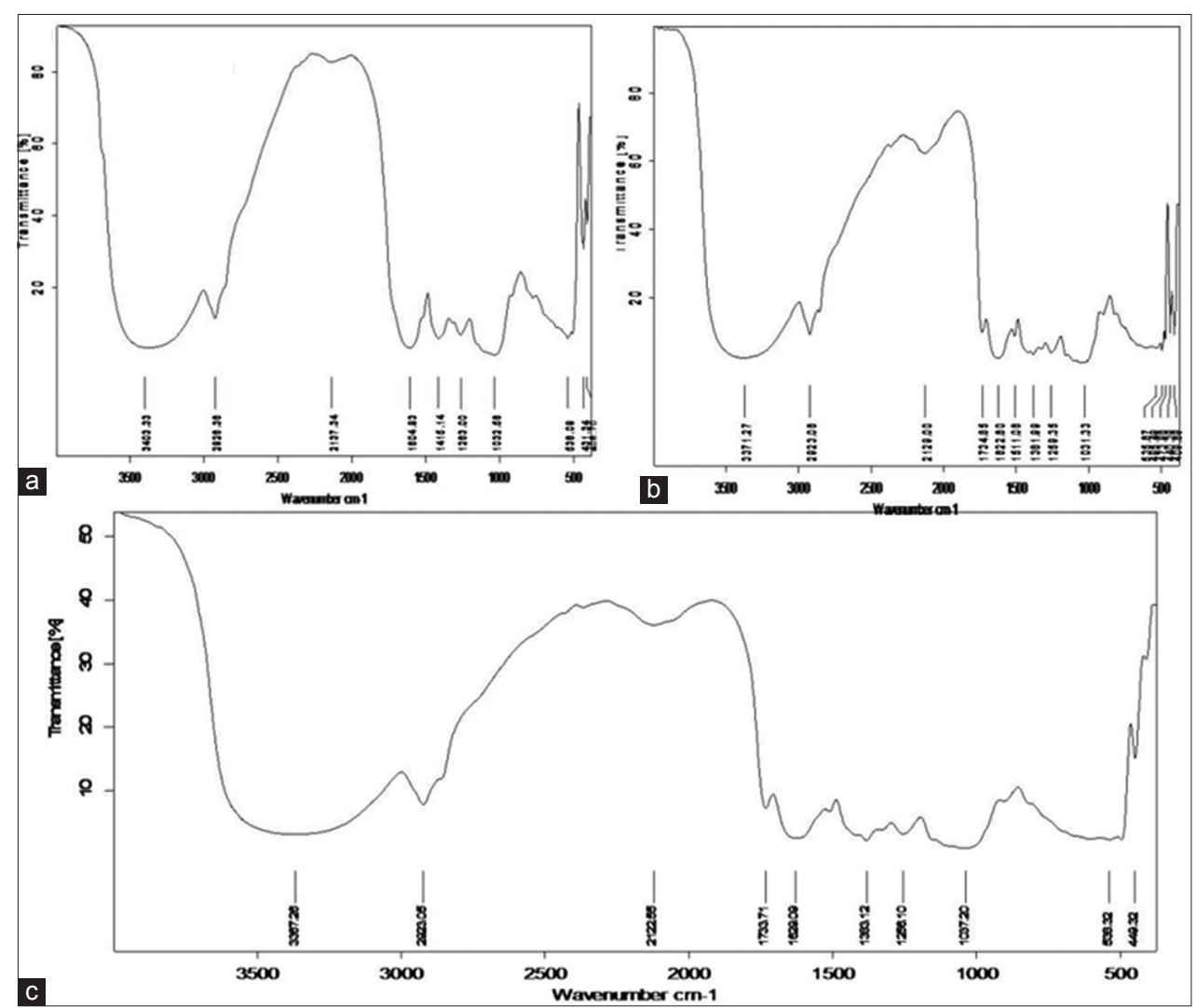

Fig. 2: Fourier transform infrared spectrum of (a) aqueous, (b) hexane, and (c) methanolic extracts of roots of Lucas aspera

Table 3: Antibacterial activity of leaf and root extracts of $L$. aspera

\begin{tabular}{|c|c|c|c|c|c|c|c|c|}
\hline \multirow[t]{2}{*}{ Bacterial strains } & \multirow[t]{2}{*}{ Conc. $(\mu \mathrm{g} / \mathrm{ml})$} & \multicolumn{3}{|l|}{ Leaf } & \multicolumn{3}{|l|}{ Root } & \multirow[t]{2}{*}{ Strp } \\
\hline & & $\mathbf{A E}$ & ME & HE & $\mathbf{A E}$ & ME & HE & \\
\hline \multirow[t]{3}{*}{ B. subtilis } & 25 & - & $2.2 \pm 0.12$ & $1.6 \pm 0.14$ & - & $1.3 \pm 0.18$ & - & 14.2 \\
\hline & 75 & $5.2 \pm 0.27$ & $9.1 \pm 0.31$ & $6.8 \pm 0.19$ & $3.6 \pm 0.18$ & $5.1 \pm 0.27$ & $4.1 \pm 0.22$ & \\
\hline & 100 & $7.4 \pm 0.29$ & $11.4 \pm 0.3$ & $8.1 \pm 0.27$ & $5.1 \pm 0.29$ & $6.3 \pm 0.22$ & $5.8 \pm 0.22$ & \\
\hline \multirow[t]{4}{*}{ S. aureus } & 25 & - & $3.0 \pm 0.21$ & $1.7 \pm 0.23$ & - & $1.1 \pm 0.2$ & - & 15.4 \\
\hline & 50 & $2.8 \pm 0.3$ & $7.1 \pm 0.32$ & $4.1 \pm 0.18$ & $2.2 \pm 0.27$ & $3.2 \pm 0.31$ & $2.4 \pm 0.21$ & \\
\hline & 75 & $5.0 \pm 0.22$ & $10.2 \pm 0.28$ & $6.1 \pm 0.16$ & $4.1 \pm 0.3$ & $5.4 \pm 0.27$ & $4.2 \pm 0.24$ & \\
\hline & 100 & $6.9 \pm 0.26$ & $12.8 \pm 0.31$ & $7.3 \pm 0.25$ & $5.3 \pm 0.29$ & $6.6 \pm 0.32$ & $6.0 \pm 0.13$ & \\
\hline \multirow[t]{4}{*}{ E. coli } & 25 & - & $1.4 \pm 0.14$ & - & - & $1.3 \pm 0.23$ & - & 12.3 \\
\hline & 50 & $2.1 \pm 0.25$ & $5.1 \pm 0.22$ & $3.0 \pm 0.19$ & $1.4 \pm 0.2$ & $2.8 \pm 0.2$ & $1.6 \pm 0.21$ & \\
\hline & 75 & $5.1 \pm 0.19$ & $7.3 \pm 0.18$ & $5.3 \pm 0.17$ & $3.1 \pm 0.18$ & $4.6 \pm 0.24$ & $4.0 \pm 0.24$ & \\
\hline & 100 & $6.6 \pm 0.22$ & $9.8 \pm 0.21$ & $6.8 \pm 0.24$ & $4.7 \pm 0.25$ & $5.8 \pm 0.21$ & $5.6 \pm 0.19$ & \\
\hline \multirow[t]{3}{*}{ P. aeruginosa } & 25 & - & - & - & - & $1.1 \pm 0.2$ & - & 13.1 \\
\hline & 50 & $2.6 \pm 0.28$ & $2.8 \pm 0.2$ & $2.5 \pm 0.19$ & $1.3 \pm 0.17$ & $2.4 \pm 0.14$ & $1.5 \pm 0.21$ & \\
\hline & 75 & $4.2 \pm 0.29$ & $4.8 \pm 0.33$ & $4.4 \pm 0.22$ & $2.8 \pm 0.14$ & $4.1 \pm 0.22$ & $4.1 \pm 0.17$ & \\
\hline
\end{tabular}

Zone of inhibition (mm) values was represented. Values are mean \pm SD ( $\mathrm{n}=3$ ). AE: Aqueous extract; ME: Methanol extract; HE: Hexane extract; Str: Streptomycin, B. subtilis: Bacillus subtilis, E. coli: Escherichia coli, S. aureus: Staphylococcus aureus, P. aeruginosa: Pseudomonas aeruginosa

$11.2 \pm 0.19 \mathrm{~mm}$, respectively, against $C$. albicans and A. niger. HE of leaves formed the inhibition zones of $7.1 \pm 0.27$ and $7.4 \pm 0.3 \mathrm{~mm}$, respectively, against $C$. albicans and $A$. niger. AE of leaves formed the inhibition zones of $6.2 \pm 0.21$ and $6.7 \pm 0.31 \mathrm{~mm}$, respectively, against $C$. albicans and $A$. niger. The standard drug nystatin $12.2 \mathrm{~mm}$ and $13.8 \mathrm{~mm}$ zone of inhibition against to $C$. albicans and A. niger, respectively.

\section{Antioxidant activity}

Antioxidant activity of different extracts of roots and leaves of L. aspera was evaluated by DPPH radical scavenging and $\mathrm{H}_{2} \mathrm{O}_{2}$ radical scavenging assays. All the extracts of leaves and roots showed RSA against DPPH and $\mathrm{H}_{2} \mathrm{O}_{2}$ free radicals (Figure 3a-d). Increase in the concentration of extracts from 25 to $100 \mu \mathrm{g} / \mathrm{ml}$ showed increase in the scavenging activity. All the extracts showed maximum scavenging activity at the highest concentration $(100 \mu \mathrm{g} / \mathrm{ml})$ of the extract. ME of the leaves exhibited maximum scavenging activity of $38.39 \pm 1.25 \%$ and $36.85 \pm 1.11 \%$, respectively, against DPPH and $\mathrm{H}_{2} \mathrm{O}_{2}$ radicals while MEs of roots exhibited maximum scavenging activity of $33.52 \pm 0.37 \%$ and $28.16 \pm 0.49 \%$, respectively, against DPPH and $\mathrm{H}_{2} \mathrm{O}_{2}$ radicals. The concentrations of the extracts required to scavenge $50 \%$ of the radicals $\left(\mathrm{IC}_{50}\right.$ values) were determined based on the linear regression curves $\left(\mathrm{R}^{2}=0.9\right)$. $\mathrm{IC}_{50}$ values were represented in Table 5 . The $\mathrm{IC}_{50}$ concentrations of ME of the leaves against DPPH and $\mathrm{H}_{2} \mathrm{O}_{2}$ radicals were determined as 136.17 and $142.42 \mu \mathrm{g} / \mathrm{ml}$, respectively. The IC ${ }_{50}$ 


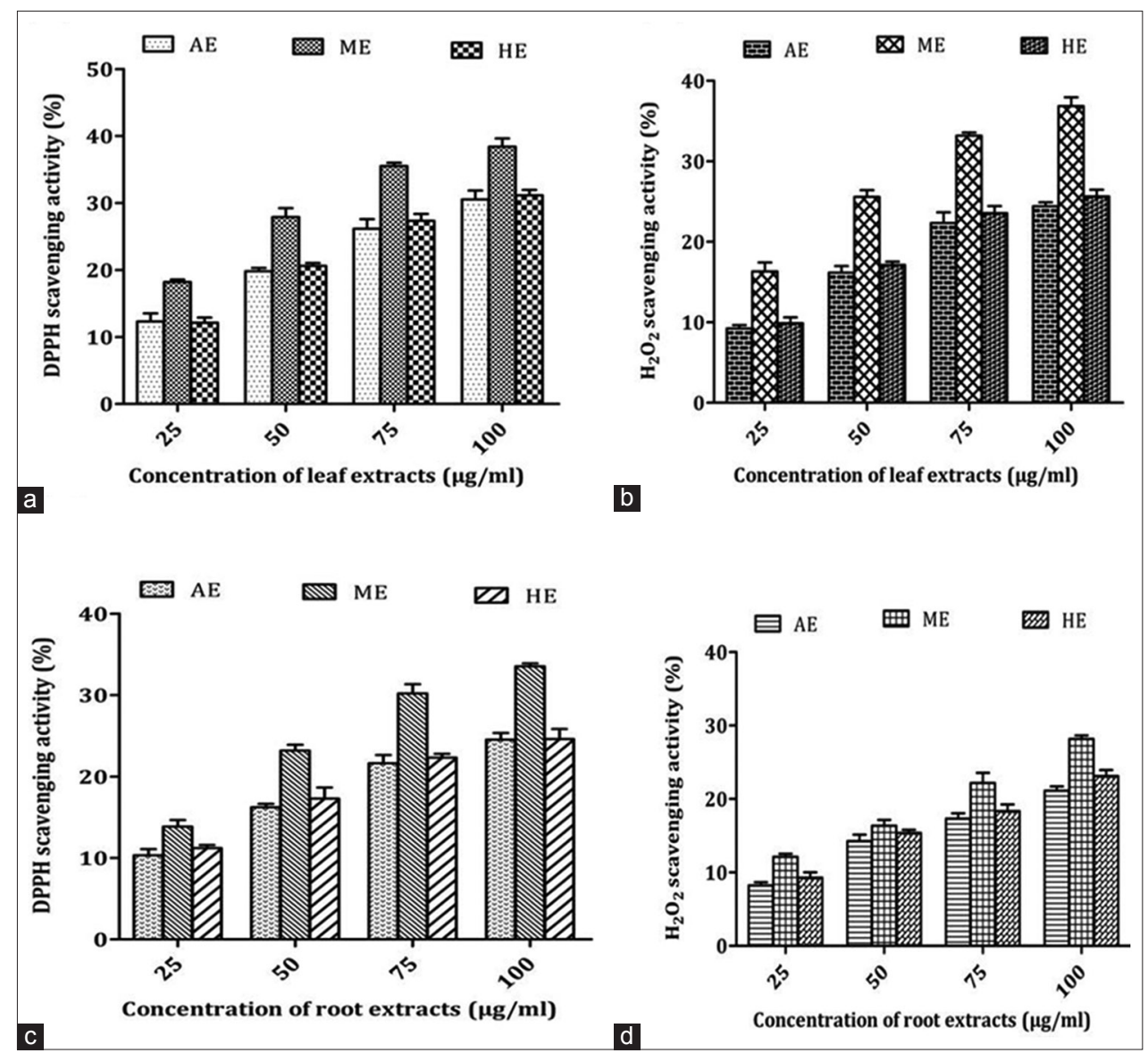

Fig. 3: Free radical scavenging activities of different extracts of leaves and roots of $L$. aspera. (a) DPPH radical scavenging activity (RSA) of leaf extracts, (b) $\mathrm{H}_{2} \mathrm{O}_{2}$ RSA of leaf extracts, (c) DPPH RSA of root extracts, (b) $\mathrm{H}_{2} \mathrm{O}_{2}$ RSA of root extracts

Table 4: Antifungal activity of leaf and root extracts of $L$. aspera

\begin{tabular}{|c|c|c|c|c|c|c|c|c|}
\hline \multirow[t]{2}{*}{ Fungal strains } & \multirow[t]{2}{*}{ Conc. $(\mu \mathrm{g} / \mathrm{ml})$} & \multicolumn{3}{|l|}{ Leaf } & \multicolumn{3}{|l|}{ Root } & \multirow[t]{2}{*}{ Nyst } \\
\hline & & $\mathbf{A E}$ & ME & HE & $\mathbf{A E}$ & ME & HE & \\
\hline \multirow[t]{3}{*}{ C. albicans } & 25 & - & $2.3 \pm 0.22$ & $1.2 \pm 0.1$ & - & - & - & \multirow[t]{3}{*}{12.2} \\
\hline & 75 & $4.3 \pm 0.22$ & $8.1 \pm 0.19$ & $5.7 \pm 0.29$ & $3.8 \pm 0.24$ & $4.6 \pm 0.31$ & $3.9 \pm 0.2$ & \\
\hline & 100 & $6.2 \pm 0.21$ & $10.3 \pm 0.27$ & $7.1 \pm 0.27$ & $5.0 \pm 0.21$ & $6.2 \pm 0.22$ & $5.1 \pm 0.18$ & \\
\hline \multirow[t]{4}{*}{ A. niger } & 25 & - & $3.0 \pm 0.23$ & $1.6 \pm 0.27$ & - & - & - & \multirow[t]{4}{*}{13.8} \\
\hline & 50 & $2.1 \pm 0.23$ & $5.9 \pm 0.28$ & $3.8 \pm 0.28$ & $1.6 \pm 0.11$ & $2.3 \pm 0.31$ & $1.9 \pm 0.11$ & \\
\hline & 75 & $4.6 \pm 0.27$ & $8.3 \pm 0.27$ & $6.1 \pm 0.22$ & $4.1 \pm 0.28$ & $5.3 \pm 0.28$ & $4.5 \pm 0.22$ & \\
\hline & 100 & $6.7 \pm 0.31$ & $11.2 \pm 0.19$ & $7.4 \pm 0.3$ & $5.3 \pm 0.27$ & $6.9 \pm 0.27$ & $5.7 \pm 0.19$ & \\
\hline
\end{tabular}

Zone of inhibition $(\mathrm{mm})$ values were represented. Values are mean \pm SD $(\mathrm{n}=3)$. AE: Aqueous extract, ME: Methanol extract, HE: Hexane extract, Nyst: Nystatin,

SD: Standard deviation, C. albicans: Candida albicans, A. niger: Aspergillus niger

Table 5: $\mathrm{IC}_{50}$ concentrations $(\mu \mathrm{g} / \mathrm{ml})$ of different extracts of L. aspera

\begin{tabular}{|c|c|c|c|c|c|c|}
\hline \multirow{3}{*}{$\begin{array}{l}\text { Antioxidant } \\
\text { assays }\end{array}$} & \multicolumn{6}{|c|}{$\mathrm{IC}_{50}$ concentrations of extracts $(\mu \mathrm{g} / \mathrm{ml})$} \\
\hline & \multicolumn{3}{|l|}{ Leaf } & \multicolumn{3}{|l|}{ Root } \\
\hline & AE & ME & HE & $\mathbf{A E}$ & ME & HE \\
\hline DPPH RSA & 177.09 & 136.17 & 169.17 & 228.35 & 156.53 & 235.72 \\
\hline $\mathrm{H}_{2} \mathrm{O}_{2} \mathrm{RSA}$ & 217.88 & 142.42 & 207.38 & 270.65 & 202.75 & 251.89 \\
\hline
\end{tabular}

AE: Aqueous extract; ME: Methanolic extract and HE: Hexane extract, $\mathrm{IC}_{50}$ : Half maximal inhibitory concentration, RSA: Radical scavenging activity

concentrations of $\mathrm{HE}$ of the leaves against DPPH and $\mathrm{H}_{2} \mathrm{O}_{2}$ radicals were determined as 169.17 and $207.38 \mu \mathrm{g} / \mathrm{ml}$, respectively. The $\mathrm{IC}_{50}$ values of $\mathrm{AE}$ of the leaves against DPPH and $\mathrm{H}_{2} \mathrm{O}_{2}$ radicals were determined as
177.09 and $217.88 \mu \mathrm{g} / \mathrm{ml}$, respectively. From the RSA values and $\mathrm{IC}_{50}$ concentrations, it is determined that MEs showed 1.2-1.5-fold more antioxidant activity compared to $\mathrm{HE}$ and $\mathrm{AE}$. The $\mathrm{IC}_{50}$ concentrations of ME of the roots against DPPH and $\mathrm{H}_{2} \mathrm{O}_{2}$ radicals were determined as 156.53 and $202.75 \mu \mathrm{g} / \mathrm{ml}$, respectively. The $\mathrm{IC}_{50}$ concentrations of $\mathrm{ME}$ of the roots against DPPH and $\mathrm{H}_{2} \mathrm{O}_{2}$ radicals were determined as 156.53 and $202.75 \mu \mathrm{g} / \mathrm{ml}$, respectively. The $\mathrm{IC}_{50}$ concentrations of $\mathrm{HE}$ of the roots against DPPH and $\mathrm{H}_{2} \mathrm{O}_{2}$ radicals were found to be 235.72 and $251.89 \mu \mathrm{g} / \mathrm{ml}$, respectively. The $\mathrm{IC}_{50}$ concentrations of AE of the roots against DPPH and $\mathrm{H}_{2} \mathrm{O}_{2}$ radicals were calculated as 228.35 and $270.65 \mu \mathrm{g} / \mathrm{ml}$, respectively.

\section{DISCUSSION}

In the present study, the phytochemical screening and FTIR analysis of root and leaf extracts of L. aspera revealed that the presence of 
carbohydrates, cholesterols, steroids, proteins, amino acids, saponins, flavonoids, alkaloids, terpenoids, tannins, and phlobatannins in ME and $\mathrm{HE}$ in $\mathrm{AE}$ except cholesterols and steroids remaining all were detected. In earlier studies, the presence of different phytochemicals was reported in L. aspera whole plant in different extracts. In that series Mangathayaru et al. [27] identified the alkaloids and nicotine in methanolic extract of L.aspera whole plant (without roots). The presence of alkaloids, glycosides, saponins, tannins, terpenoids, and flavonoids were reported in ethanol, hexane, and ethyl acetate extracts [28]. High amounts of glycosides, tannins, and flavonoids observed in ethanolic extract, while the other two extracts contain moderate amount of the chemical constituents [28]. In ethanol extract of the whole plant reported with all major phytochemicals [29]. In another study, except flavonoids and tannins, others phytochemicals were reported in the whole plant of L. aspera in MEs [30]. The presence of different phytochemicals in the same plant is due to solvents which were used to extract preparations and plant parts selected. The occurrence of these secondary metabolites suggests that the plant might be of medicinal importance. It was reported that the presence of phenols, tannins, and flavonoids exhibits different pharmacological activities such as antimicrobial [31,32], antioxidant $[33,34]$, anti-inflammatory $[35,36]$, and anticancer $[33,37]$.

Antimicrobial activity of $L$. aspera leaf and root extracts observed in this study, antibacterial studies of $L$. aspera showed that leaf extracts exhibited effective activity compared with root extracts. Among the different extracts, MEs showed potential activity compared with HE and AE. Among the different bacteria used in this study, Gram-positive bacteria were more susceptible than the Gram-negative bacteria to L. aspera extracts. The results of the antibacterial activity are very effective and are in line with many earlier antimicrobial studies of plant extracts. Earlier ME of leaf showed potent antibacterial activity against to E. coli, Klebsiella, Pseudomonas, and Staphylococcus aureus [38]. Similarly, ME of root, leaf, stem, and flower showed 7.0-11.0 nm zone of inhibition against selected bacteria [39]. Among all parts, root showed high antibacterial activity against E. coli, S. aureus, S. choleraesuis, $S$. typhimurium, S. flexneri, and P. aeruginosa and leaf extract showed against to S. aureus, S. choleraesuis, S. typhimurium, and S. flexneri [39]. In another study, whole plant ethyl acetate and MEs of $L$. aspera showed moderate to high and concentration-dependent antibacterial activity against all the tested bacterial strains [30]. Similarly, whole plant ME and ethanol showed antibacterial activity against to B. cereus, B. megaterium, B. subtilis, P. aeruginosa, S. paratyphi, S. typhi, S. dysenteriae, S. sonnei, and $S$. aureusi [40]. Leaf extract of L. aspera from methanol, ethyl acetate, and petroleum ether showed potential antibacterial activity at $1 \mathrm{mg} /$ disc in other study [41]. Many scientists tried to elucidate the plausible mechanism of action of the antimicrobial activity of plant extracts. Triterpenoids or saponins present in the extracts could form pore-like structures and cause the dissipation of membrane electrical potential or membrane proton motive force, and thus membrane destruction occurs [42].

MEs of roots and leaves of L. aspera showed highest inhibitory activity against selected fungi than $\mathrm{HE}$ and $\mathrm{AE}$. The present results agreement with the earlier study, methanol, ethyl acetate, and petroleum ether leaf extract of $L$. aspera showed potential antifungal activity at $1 \mathrm{mg} /$ disc against to Aspergillus fumigates, Botryodiplodia theobromae, Colletotrichum corchori, Curvularia lunata, and Fusarium equiseti but not to C. albicans and Saccharomyces cerevisiae [41]. Similar to this in another study, methanol and ethanol of whole plant extract showed potent antifungal activity against to $F$ e equiseti, B. theobromae, and $C$. corchori [40]. FTIR analysis and phytochemical screening revealed that plant secondary metabolites present in the extracts can perturb the fungal cell wall and also caused the release of cellular components such as ions and intracellular proteins which, in turn, halt the growth of fungi. It had long been documented that plants metabolites saponins, tannins, and alkaloids are known for antimicrobial activity [43].

Antioxidants or radical scavengers are the compounds of bio or synthetic origin that protect the cells from various damaging effects and diseases caused by reactive oxygen species. In addition, naturally occurring antioxidants can be formulated to give nutraceuticals, which can help to prevent oxidative damage from occurring in the body. Assays associated with lipid peroxidations is a common method for estimation of antioxidant activity; however, estimation of stable free radical DPPH is other method used in plants other natural sources $[44,45]$. In the present study, free radical scavenger levels of $\mathrm{H}_{2} \mathrm{O}_{2}$ and DPPH were observed in $\mathrm{ME}, \mathrm{AE}$, and $\mathrm{HE}$ leaf and root extract of $L$. aspera. The levels of free radical scavengers increased with dose-dependent in all extracts and ME of leaf showed high antioxidant activity compared with root extracts. Antioxidant or RSA of the different extracts is mainly due to the presence of hydrogen-donating molecules such as proteins, flavonoids, and terpenoids and other biomolecules are present in the extracts. Antioxidant activity of $L$. aspera with different extracts produced in this study is consistent with earlier reports $[28,38,39,46]$. Apart L. aspera, numerous plant components have proven to show antioxidants activity $[28,47]$. Previous reports emphasized that tannins and flavonoids are natural antioxidants that could play the main role in the antioxidant activity of the plant extracts. Besides, these alkaloids are natural antioxidants used for medicinal and commercial needs [48]. The presence of alkaloids, terpenoids, and flavonoids could be responsible for the antioxidant activities of the L. aspera extracts.

\section{CONCLUSION}

All the extracts showed antibacterial and antifungal activity with maximum inhibition against to selected microorganisms. MEs of leaf exhibited maximum antibacterial, antifungal, and highest RSA. Phytochemical screening and FTIR analysis revealed that alkaloids, triterpenoids, and flavonoids could be responsible for the antimicrobial and antioxidant activities, respectively, of the $L$. aspera extracts. From the present results, it is concluded that compounds of L. aspera can be used as antimicrobial agents and ingredients in the antioxidant formulations in different food and pharmaceutical fields.

\section{ACKNOWLEDGMENTS}

The authors are thankful to the Head, Department of Biotechnology, Tirupati, for providing the laboratory facilities. Authors are also thankful to DST-CURIE, Central Instrumentation Facility, Sri Padmavati Mahila Visvavidyalayam (Women's University) Tirupati, for providing permission to utilize FTIR for analysis of plant material.

\section{AUTHORS' CONTRIBUTIONS}

BK conceived the idea, participated in designing, and supervised the work. KV and MB conducted the experiments; $\mathrm{AD}$ monitored the work progress. BK, KV and DA drafted the manuscript for publication. All authors read and approved the final manuscript.

\section{CONFLICTS OF INTEREST}

The author(s) declare that they have no conflicts of interest with respect to the research work, authorship, and publication of this article.

\section{REFERENCES}

1. Hamil FA, Apiob S, Mubirub NK, Zirabac RB, Mosangoc M, Maganyic OW, et al. Traditional herbal drugs of Southern Uganda, II: Literature analysis and antimicrobial assays. J Ethnopharm 2003;84:57-78.

2. Barbour EK, Al Sharif M, Sagherian VK, Habre AN, Talhouk RS, Talhouk SN, et al. Screening of selected indigenous plants of Lebanon for antimicrobial activity. J Ethnopharmacol 2004;93:1-7.

3. Gislene GF, Locatelli J, Freitas CP, Silva LG. Antibacterial activity of plant extracts and phytochemicals on antibiotic resistant bacteria. $\mathrm{Br} \mathrm{J}$ Microbiol 2000;31:247-56.

4. Ríos JL, Recio MC. Medicinal plants and antimicrobial activity. J Ethnopharmacol 2005;100:80-4.

5. Dabur R, Gupta A, Mandal TK, Singh DD, Bajpai V, Gurav AM, et al. Antimicrobial activity of some Indian medicinal plants. Afr J Tradit Complement Altern Med 2007;4:313-8.

6. Selvamohan T, Ramadas V, Kishore SS. Antimicrobial activity of 
selected medicinal plants against some selected human pathogenic bacteria. Adv App Sci Res 2012;3:3374-81.

7. Amenu D. Antimicrobial activity of medicinal plant extracts and their synergistic effect on some selected pathogens. Am J Ethnomed 2014;11:18-29.

8. Javid T, Adnan M, Tariq A, Akhtar B. Antimicrobial activity of three medicinal plants (Artemisia indica, Medicago falcata and Tecoma stans). Afr J Tradit Complement Altern Med 2015;12:91-6.

9. Sulieman AM, Shaarawy SM, Alghamdi AA. Evaluation of antimicrobial and synergistic effects of selected medicinal plants of Hail area with antibiotics. Biosci Biotech Res Comm 2017;10:44-50.

10. Shahidi F. Natural Antioxidants Chemistry, Health Effects and Applications. $8^{\text {th }}$ ed. Champaign: AOCS Press; 1997. p. 414

11. Duduku K, Nithyanandam R, Sarbatly R. Phytochemical constituents and activities of Morinda citrifolia L. and Universiti Malaysia Sabah. In: Phytochemicals - A Global Perspective of Their Role in Nutrition and Health. Ch. 6. Malaysia: InTech; 2012. p. 127-50.

12. Zhang YJ, Gan RY, Li S, Zhou Y, Li AN, Xu DP, et al. Antioxidant phytochemicals for the prevention and treatment of chronic diseases. Molecules 2015;20:21138-56.

13. Panche AN, Diwan AD, Chandra SR. Flavonoids: An overview. J Nutri sci 2016;47:1-15.

14. Mandal SM, Dey S. LC-MALDI-TOF MS-based rapid identification of phenolic acids. J Biomol Tech 2008;19:116-21.

15. Sasidharan S, Chen Y, Saravanan D, Sundram KM, Yoga Latha L. Extraction, isolation and characterization of bioactive compounds from plants' extracts. Afr J Tradit Complement Altern Med 2011;8:1-0.

16. Thamizhanban D, Rani TG, Pravalika P. A review on hyphenated separation techniques used in pharmaceutical analysis. IOSR J Pharm Bio Sci 2016;11:65-74

17. Prajapati MS, Patel JB, Modi K, Shah MB. Leucas aspera: A review. Pharmacogn Rev 2010;4:85-7.

18. Karthikeyan S, Sivakumar A, Anbalagan M, Nalini E, Gothandam KM. Finger printing of alkaloids, steroids and flavonoids using HPTLC of Leucas aspera L. Whole plant methanolic extract. J Pharm Sci Res 2013;5:67-71

19. Chouhan SH, Singh KS. A review of plants of genus Leucas. J Pharm Phytothe 2011; 3(3): 13-26.

20. Vijay kumar G, Devanna N. An Update of Leucas aspera-A medicinal plant (Review). Int J Sci Res Med Human 2016;5:485-503.

21. Harborne JB. Phytochemical Methods, A Guide to Modern Techniques of Plant Analysis. $2^{\text {nd }}$ ed. New York: Chapman and Hall; 1998.

22. Ramamurthy N, Kannan S. Fourier transform infrared spectroscopic analysis of a plant (Calotropis gigantea Linn) from an industrial village, Cuddalore Dt, Tamilnadu, India. Rom J Biophys 2007:17:269.

23. Cruickshank R. Medical Microbiology: A Guide to Diagnosis and Control of Infection. Edinburgh: E \& S Livingston Ltd.; 1968.

24. Netala VR, Kotakadi VS, Bobbu P, Gaddam SA, Tartte V. Endophytic fungal isolate mediated biosynthesis of silver nanoparticles and their free radical scavenging activity and anti microbial studies 3 Biotech 2016;6:132.

25. Rammohan A, Gunasekar D, Reddy NV, Vijaya T, Devillee A, Bodo B, et al. Structure elucidation and antioxidant activity of the phenolic compounds from rhynchosia suaveolens. Nat Prod Commun 2015;10:609-11.

26. Patel A, Patel A, Patel A, Patel NM. Determination of polyphenols and free radical scavenging activity of tephrosia purpurea linn leaves (Leguminosae). Pharmacognosy Res 2010;2:152-8.

27. Mangathayaru K, Thirumurugan D, Patel PS, Pratap DV, David DJ, Karthikeyan J. Isolation and identification of nicotine from Leucas aspera (wild) Lin. Int J Pharm Sci 2006;68:88-90.
28. Das K, Das B, Arpita FK, Morshed MA, Uddin A, Bhattacherjee R, et al. Phytochemical screening and antioxidant activity of Leucas aspera. Int J Pharm Sci Res 2011;2:1746-52.

29. Gupta N, Subhramanyam EV, Sharma RK. Antidiabetic and hypoglycaemic activity of the crude extracts of the plant Leucas aspera. Int J Phar Inn 2011;1:1-9.

30. Ilango K, Ramya S, Gopinath G. Antibacterial activity of Leucas aspera spreng. Int J Chem Sci 2008;6:526-30.

31. Sengul M, Yildiz H, Gungor N, Cetin B, Eser Z, Ercisli S, et al. Total phenolic content, antioxidant and antimicrobial activities of some medicinal plants. Pak J Pharm Sci 2009;22:102-6

32. Karimi E, Oskoueian E, Hendra R, Oskoueian A, Jaafar HZ. Phenolic compounds characterization and biological activities of citrus aurantium bloom. Molecules 2012;17:1203-18.

33. Khacha-ananda S, Tragoolpua K, Chantawannakul P, Tragoolpua Y. Antioxidant and anti-cancer cell proliferation activity of propolis extracts from two extraction methods. Asian Pac J Cancer Prev 2013;14:6991-5.

34. Pourmorad F, Hosseinimehr SJ, Shahabimajd N. Antioxidant activity, phenol and flavonoid contents of some selected Iranian medicinal plants. Afr J Biotech 2006;11:1142-5.

35. Capelari-Oliveira P, Paula CA, Rezende SA, Campos FT, GrabeGuimarães A, Lombardi JA, et al. Anti-inflammatory activity of Lychnophora passerina, Asteraceae (Brazilian "Arnica"). J Ethnopharmacol 2011;135:393-8.

36. Rathee P, Chaudhary H, Rathee S, Rathee D, Kumar V, Kohli K, et al. Mechanism of action of flavonoids as anti-inflammatory agents: A review. Inflamm Allergy Drug Targets 2009;8:229-35.

37. Lin Y, Shi R, Wang X, Shen HM. Luteolin, a flavonoid with potential for cancer prevention and therapy. Curr Cancer Drug Targets 2008;8:634-46.

38. Tahareen S, Shwetha R, Myrene RD. Potential antioxidant, antiinflammatory and antibacterial evaluation of extracts of Leucas aspera using in vitro model. Int J Pharm Pharm Sci 2016;8:292-7.

39. Chew AL, Jessica JJ, Sasidharan S. Antioxidant and antibacterial activity of different parts of Leucas aspera. Asian Pac J Trop Biomed 2012;2:176-80

40. Nagarasan S, Boominathan M. Perspective pharmacological activities of Leucas aspera: An indigenous plant species. Indo Am J Pharm Res 2016;6:6567-72.

41. Akter M, Khan MA, Muhsin MD, Hamid K, Ullah MO, Bulbul IJ, et al. In vitro studies on antibacterial, antifungal, and cytotoxic properties of Leucas aspera. Bio Med 2012;4:183-7.

42. Netala VR, Ghosh SB, Bobbu PL, Dandu A, Tartte V. Triterpenoid saponins: A review on biosynthesis, applications and mechanism of their action. Int J Pharm Pharm Sci 2015;7:24-8.

43. Tschesche R. Advances in the chemistry of antibiotics substances from higher plants Pharm Phytochem 1970;3:274-89.

44. Molyneux P. The use of the stable free radical diphenylpicrylhydrazyl (DPPH) for estimating antioxidant activity. Songklanakarin J Sci Technol 2004:26:211-9.

45. Moon J, Schibamoto T. Antioxidant assays for plant and food components. J Agri Food Chem 2009;57:1655-66.

46. Aruoma OI, Cuppett SL. Antioxidant Methodology In Vivo and In Vitro Concepts. Champaign: AOCS Press; 1997. p. 41-172.

47. Sowndhararajan K, Kang SC. Free radical scavenging activity from different extracts of leaves of bauhinia vahlii wight and arn. Saudi J Biol Sci 2013;20:319-25

48. Benabdesselam FM, Khentache S, Bougoffa K, Chibane M. Antioxidant activities of alkaloid extracts of two Algerian species of Fumaria: Fumaria capreolata and Fumaria bastardii. Rec Adv Nat Prod 2007;1:28-35. 